\title{
A method of rapid in vitro proliferation and morphological characterization of the medicinal plant Aloe vera $L$.
}

\author{
Chandra Sekhar Singh B. ${ }^{{ }^{*}}$, Diriba Adugna A. ${ }^{1}$ and Roja Rani A. ${ }^{2}$ \\ ${ }^{1}$ Department of Plant Science, College of Agriculture and Ambo University, Ambo, Post Box: 19, Ethiopia. \\ ${ }^{2}$ Department of Genetics and Biotechnology, Osmania University, Hyderabad-500007, India.
}

Received 12 September, 2017; Accepted 30 October, 2017

\begin{abstract}
Morphological characterization was carried out on Aloe vera (Aloe barbadensis Miller) accessions collected from different locations in India. The experiments were conducted on 12 Aloe accessions and the leaf length, width, thickness, stem length, and thickness were measured using vernier calipers. The plantlets were chemically treated with $2.5 \%(\mathrm{w} / \mathrm{v})$ of sodium hypochlorite which is an alternative safer surface sterilization method for replacement of mercury chloride by using shoot tip as explants. The sterilization results indicate that the highest number $(93 \%)$ of viable explants (10) with the best regeneration potential was in Murashige and Skoog (MS) medium compared with other treatments. Multiple shoots/explants (35) were found in MS medium containing 6-benzylaminopurine (BAP, $1.5 \mathrm{mgL}^{-}$ '; kinetin (0.5 mgL ${ }^{-1}$ ), indole-3-butyric acid (IBA, $0.2 \mathrm{mg} \mathrm{L}^{-1}$ ), indole-3-acetic acid (IAA, $0.1 \mathrm{mg} \mathrm{L}^{-1}$ ), and naphthalene acetic acid (NAA, $0.2 \mathrm{mg} \mathrm{L}^{-1}$ ). Based on the shoot proliferation, a maximum number $(87.89 \%)$ of shoots obtained from the micro-shoot culture method and a maximum number $(91.12 \%)$ of roots were obtained on MS medium supplemented with NAA $\left(0.2 \mathrm{mg} \mathrm{L}^{-1}\right)$, IBA $\left(0.2 \mathrm{mgL}^{-1}\right)$ and IAA $(0.1$ $\mathrm{mgL}^{-1}$ ) which was found to be the best. The healthy rooted plantlets were successfully transferred and obtained as the plants were of $100 \%$ survival. The regenerated plants were morphologically similar to the mother plant.
\end{abstract}

Key words: Aloe vera, morphology, micro propagation, sodium hypochlorite, shoots tips, efficient method, medicinal plant.

\section{INTRODUCTION}

Aloe vera L. (Aloe barbadensis Mill.) belonging to the family Liliaceae (Xanthorrhoeaceae) is an important perennial, xerophytic, medicinal, succulent herb and the genus comprises about 300 perennial species. Generally,
Aloe species are identified by their leaf structure, characteristics, inflorescences and rosettes of succulent leaves (Singh et al., 2013). Aloe can grow in nutritionally poor soil and it has great demand in pharmaceutical and

*Corresponding author. E-mail: singhsekhar960@gmail.com. Tel: +91 7619180292.

Author(s) agree that this article remains permanently open access under the terms of the Creative Commons Attribution License 4.0 International License 
cosmetic industry. The plant has green fleshy leaves covered by a thick cuticle or rind and an inner clear pulp (Williams et al., 2010). Aloe is used externally for the treatment of burns, scalds, skin irritation, sunburn wounds, psoriasis, acne, dermatitis, eczema, and ulcers. The plant has numerous pharmacological values like antioxidant, anti-inflammatory, antidiabetic, anti-microbial, anti-fungal, anti-viral, anti-tumor, antiseptic, anti-aging, and other properties (Paoulomi et al., 2013). Administration of gel extract reduces blood glucose levels, blood urea and glycosylated haemoglobin (Rajasekaran et al., 2005).

In additional to the pharmaceutical applications, Aloe vera is widely used in food and cosmetic industry. In the food industry, it is used as an ingredient for health drinks, desserts and beverages and yogurt (Reynolds, 2004). In addition to the medical applications, Aloe vera has been introduced in cultivation as ornamental and house hold plant. The morphological studies are very important for cultivating the high quality of the Aloe gemplasm.

Aloe is generally propagated by suckers arising from the base of the mother plant and natural vegetative propagation of Aloe is very slow. Earlier studies showed that Aloe vera has been sterilized using the mercuric chloride which is harmful for the environment and also has effect on kidney, liver, adrenal and fertility (WHO, 2005). Mercury chloride $\left(\mathrm{HgCl}_{2}\right)$ is biotransformed into methyl mercury chloride $\left(\mathrm{CH}_{3} \mathrm{HgCl}\right)$ and causes adequate environmental effects by human consumption of contaminated fish, shellfish, and algae (Silva-Pereira, 2005). The alternative method for rapid multiplication of selected genotypes is possible by using sodium hypochlorite, which is the main objective of the present study.

Tissue culture of different Aloe spp. was reported by many researchers. Cytokinins are one of the most important growth regulators affecting the shoot proliferation (Garland and Stolz, 1981). This research work which deals with the use of shoot tip and apical meristem for micro propagation have been proposed by Debiasi et al. (2007) and Campestrini et al. (2006). Acclimatization of rooted plantlets in pots containing a mixture of sand, silt and compost under greenhouse conditions with 80 to $90 \%$ of moisture is suited for young plants survival (Hirimburegama and Gamage, 1995). Currently, it is necessary to develop efficient regeneration method for Aloe cultivation to meet the high demand, particularly, for plant genetic transformation and cloning techniques (Velcheva et al., 2005). Micro propagation of various accessions of Aloe from different regions in India has not been reported so far. Several studies have reported about rapid in vitro propagation of Aloe vera (Albanyl, 2006). Regeneration of Aloe vera in nature is very slow due to its male sterility which forms a barrier in rapid propagation. Aloe is an exclusively propagated crop using lateral buds or off shoots produced by donor plant. A single plant usually produces 2 to 3 off shoots in a year which is not sufficient for undertaking commercial cultivation and to meet the industrial demand.

The main objective of this study was to develop a rapid, efficient, cost effective, and easy method of micropropagation of Aloe vera at commercial level. In this study, media composition with new combinations and concentrations of different growth regulators for efficient and rapid micro propagation of Aloe vera was standardized using shoot tip explants.

\section{MATERIALS AND METHODS}

\section{Collection of ex-plant material}

This study was carried out on germplasm of Aloe vera ( $A$. barbadensis Miller), an important medicinal and ornamental plant collected from different places such as National Bureau of Plant Genetic Resources (NBPGR), New Delhi and Central Institute of Medicinal and Aromatic Plants (CIMAP), Boduppal, Hyderabad, India. The experimental plant material consists of 12 accessions of Aloe vera ( $A$. barbadensis Miller); among them, 10 accessions were collected from NBPGR, voucher no: NBPGR/ 2011/1771 dated 1107-2011 from different geographical regions of India from Rajasthan (IC111267, IC111269, IC111271, IC111272), Gujarat (IC111279), Haryana (IC111280), and Delhi (IC471882, IC471883, IC471884, IC471885), respectively and 2 accessions of Aloe CIM-Sheetal (CAL 14) and wild Aloe vera (local) were collected from CIMAP, voucher no: CIMAP/63/6222 dated 20-07-2011. All the plants used in this study were about two years of age. High potential accessions showed the highest incidence in morphological studies which are as shown in Figure 1a to $f$ and the details of 12 accessions grown at Indian Immunologicals Ltd. Shown in Table 1.

All the accessions were examined for a number of morphological parameters; from each accession, 5 mature plants were randomly selected and the observations were recorded and mean data were used for statistical analysis. Morphological data of 12 individuals were observed. The data was transformed into numerical form and was analyzed by Newman-Kuel's multiple comparisons test. While studying Aloe genus, various characters such as number of leaves, number of suckers, leaf width/breadth $(\mathrm{cm})$, stem length $(\mathrm{cm})$, peduncle length $(\mathrm{mm})$, leaf thickness (density of leaf) $(\mathrm{mm})$, gel fresh weight $(\mathrm{g})$, leaf dry weight $(\mathrm{g})$, biomass $(\mathrm{g})$, root length $(\mathrm{cm})$, and Aloin concentration (\%) were considered.

\section{Sterilization of explants}

The shoot apices were washed thoroughly under running tap water for $30 \mathrm{~min}$ to remove all the adhering dust particles and microbes from the surface. The explants were then washed with $0.1 \%$ of liquid detergent (Labolene, France) for another $30 \mathrm{~min}$ and then rinsed several times with distilled water to remove detergent. The explants were then treated with $1 \%$ of Bavistin (systemic fungicide) and $0.25 \%$ of Dithane $\mathrm{M}-45$ for $30 \mathrm{~min}$, and were washed with distilled water. Then, were later treated with ampicilin (systemic bactericide) along with streptomycin for $30 \mathrm{~min}$ each to eliminate fungus and bacteria and the fungicide and bactericide were washed out with sterilized distilled water. Under the sterile conditions, explants were rinsed with isopropyl alcohol for $45 \mathrm{~s}$ and then 10 explants were treated with $2.5 \%$ sodium hypochlorite $(10 \%$ Clorox) for $30 \mathrm{~min}$. The explants were then thoroughly washed (4 to 5 washings) with sterilized distilled water to remove the traces of sodium hypochlorite and were trimmed to remove extra outer portion of stem discs and carefully cultured in sterile culture bottles containing $40 \mathrm{ml}$ of MS medium under laminar air flow hood 

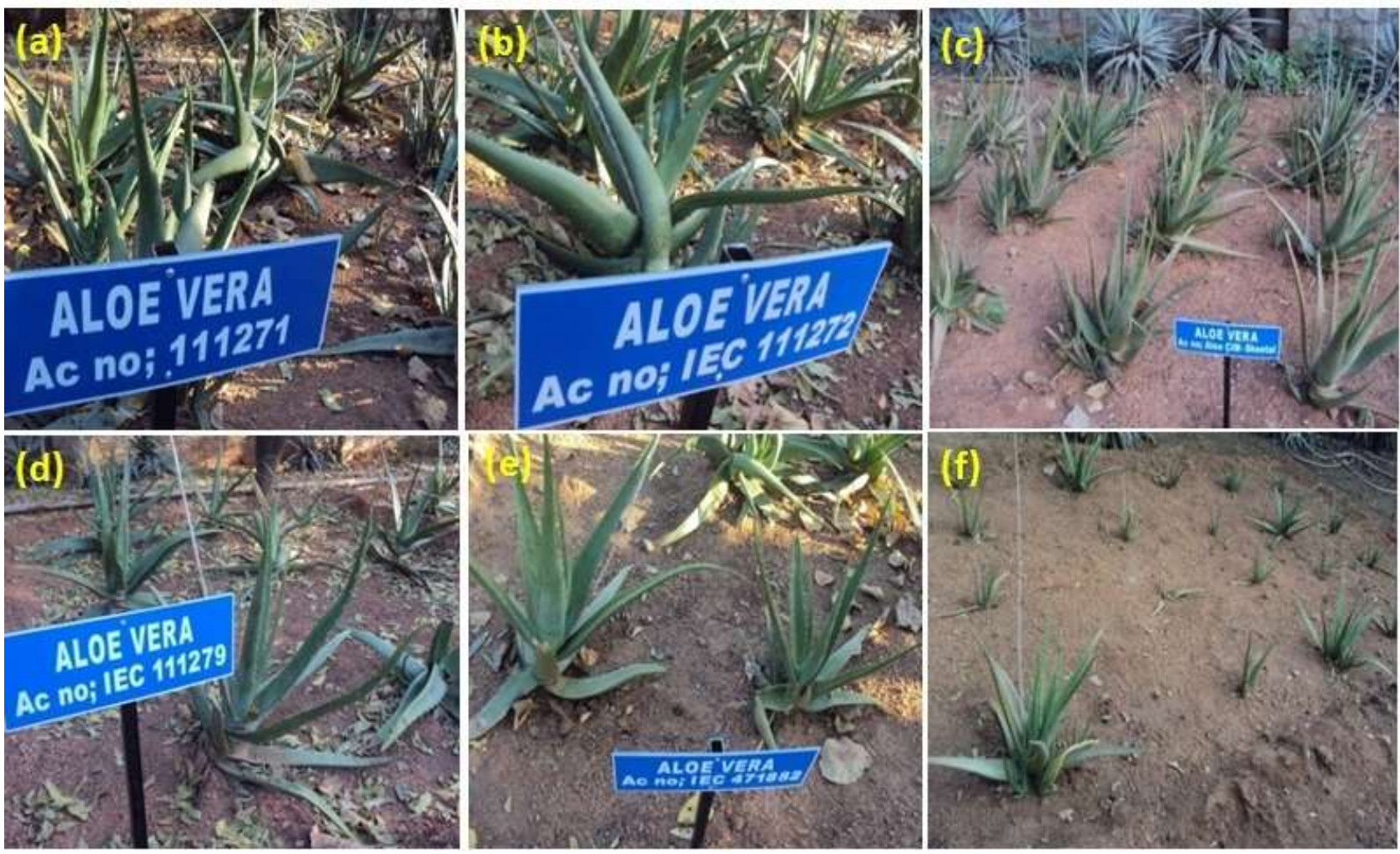

Figure 1. High potential accessions of Aloe vera shown for morphological and in vitro studies. (a) Aloe barbadensis Mill IC111271; (b) Aloe barbadensis Mill IC111272; (c) Aloe barbadensis Mill Aloe CIM-Sheetal; (d) Aloe barbadensis Mill IC111279; (e) Aloe barbadensis Mill IC471882; (f). Aloe barbadensis Mill Aloe vera (local).

Table 1. Details of Aloe vera accessions used for morphological and in vitro studies.

\begin{tabular}{llll}
\hline Specie & Accession & Obtained from & Source \\
\hline Aloe barbadensis Mill & IC 111267 & Rajasthan & NBPGR, New Delhi \\
Aloe barbadensis Mill & IC 111269 & Rajasthan & NBPGR, New Delhi \\
Aloe barbadensis Mill & IC 111271 & Rajasthan & NBPGR, New Delhi \\
Aloe barbadensis Mill & IC 111272 & Rajasthan & NBPGR, New Delhi \\
Aloe barbadensis Mill & IC 111279 & Gujarat & NBPGR, New Delhi \\
Aloe barbadensis Mill & IC 111280 & Haryana & NBPGR, New Delhi \\
Aloe barbadensis Mill & IC471882 & Delhi & NBPGR \\
Aloe barbadensis Mill & IC471883 & Delhi & NBPGR \\
Aloe barbadensis Mill & IC471884 & Delhi & NBBPGR \\
Aloe barbadensis Mill & IC471885 & Delhi & NBPGR \\
Aloe barbadensis Mill & Aloe CIM-Sheetal (CAL14) & Uttarpradesh & CIMAP, Hyderabad \\
Aloe barbadensis Mill & wild Aloe vera (local) & Telangana & CIMAP, Hyderabad \\
\hline
\end{tabular}

(Murashige and Skoog, 1962). After sterilization, shoot apices were directly inoculated into different concentrations of media for shoot elongation (Ahmed et al., 2007).

\section{Culture medium}

The basal medium contains Murashige and Skoog (MS) medium salts, vitamins, $3 \%$ sucrose and agar. The basal media was supplemented with various concentration and combination of growth regulators: 2, 4-D, 6-benzylaminopurine (BAP), naphthalene acetic acid (NAA), kinetin (KIN), indole-3-butric acid (IBA), and indole-3-acetic acid (IA). Sucrose (3\%) was used as carbon source and media were solidified with agar $(0.7 \%)$. Preparation of media ingredients and their concentrations as per MS medium are shown in Table 2. The medium was adjusted to $\mathrm{pH} 5.9$ prior to autoclaving at $121^{\circ} \mathrm{C}$ and $15 \mathrm{lbs}$ pressure for $20 \mathrm{~min}$. The reagent grade chemicals were obtained from Fischer Scientifics and Hi Media 
Table 2. Preparation of media ingredients and their concentrations as per Murashige and Skoogs.

\begin{tabular}{|c|c|c|c|c|c|c|c|}
\hline Component & IM & MM-1 & MM-2 & MM-3 & MM-4 & RM-1 & RM-2 \\
\hline $\mathrm{KNO}_{3}$ & 1900 & 1900 & 1900 & 1900 & 1900 & 1900 & 1900 \\
\hline $\mathrm{NH}_{4} \mathrm{NO}_{3}$ & 1650 & 1650 & 1650 & 1650 & 1650 & 1650 & 1650 \\
\hline $\mathrm{CaNO}_{3}$ & - & - & - & - & - & - & - \\
\hline $\mathrm{Cacl}_{2} .2 \mathrm{H}_{2} \mathrm{O}$ & 440 & 440 & 440 & 440 & 440 & 440 & 440 \\
\hline $\mathrm{MgSO}_{4} \cdot 7 \mathrm{H}_{2} \mathrm{O}$ & 370 & 370 & 370 & 370 & 370 & 370 & 370 \\
\hline $\mathrm{KH}_{2} \mathrm{PO}_{4}$ & 170 & 170 & 170 & 170 & 170 & 170 & 170 \\
\hline $\mathrm{MnSO}_{4} \cdot 4 \mathrm{H}_{2} \mathrm{O}$ & 22.3 & 22.3 & 22.3 & 22.3 & 22.3 & 22.3 & 22.3 \\
\hline $\mathrm{ZnSO}_{4} .7 \mathrm{H}_{2} \mathrm{O}$ & 8.6 & 8.6 & 8.6 & 8.6 & 8.6 & 8.6 & 8.6 \\
\hline $\mathrm{FeSO}_{4} .7 \mathrm{H}_{2} \mathrm{O}$ & 27.85 & 27.85 & 27.85 & 27.85 & 27.85 & 27.85 & 27.85 \\
\hline $\mathrm{Na}_{2}$. EDTA. $2 \mathrm{H}_{2} \mathrm{O}$ & 37.3 & 37.3 & 37.3 & 37.3 & 37.3 & 37.3 & 37.3 \\
\hline $\mathrm{COC}_{1} .6 \mathrm{H}_{2} \mathrm{O}$ & 0.025 & 0.025 & 0.025 & 0.025 & 0.025 & 0.025 & 0.025 \\
\hline $\mathrm{CuSO}_{4} .5 \mathrm{H}_{2} \mathrm{O}$ & 0.025 & 0.025 & 0.025 & 0.025 & 0.025 & 0.025 & 0.025 \\
\hline $\mathrm{Na}_{2} \mathrm{MoO}_{4} \cdot 2 \mathrm{H}_{2} \mathrm{O}$ & 0.25 & 0.25 & 0.25 & 0.25 & 0.25 & 0.25 & 0.25 \\
\hline $\mathrm{H}_{3} \mathrm{BO}_{3}$ & 6.2 & 6.2 & 6.2 & 6.2 & 6.2 & 6.2 & 6.2 \\
\hline $\mathrm{KI}$ & 0.83 & 0.83 & 0.83 & 0.83 & 0.83 & 0.83 & 0.83 \\
\hline Thiamine $\mathrm{HCl}$ & 0.1 & 0.1 & 0.1 & 0.1 & 0.1 & 0.1 & 0.1 \\
\hline Pyridoxin $\mathrm{HCl}$ & 0.5 & 0.5 & 0.5 & 0.5 & 0.5 & 0.5 & 0.5 \\
\hline Nicotinic acid & 0.5 & 0.5 & 0.5 & 0.5 & 0.5 & 0.5 & 0.5 \\
\hline Meso inositol & 100 & 100 & 100 & 100 & 100 & 100 & 100 \\
\hline Sucrose & 30000 & 30000 & 30000 & 30000 & 30000 & 30000 & 30000 \\
\hline Agar & 7000 & 7000 & 7000 & 7000 & 7000 & 7000 & 7000 \\
\hline Kinetin & - & - & 0.5 & 0.5 & 0.5 & - & - \\
\hline NAA & - & 0.1 & 0.2 & 0.2 & 0.2 & - & 0.2 \\
\hline IAA & 0.3 & 0.1 & 0.1 & 0.1 & 0.1 & - & 0.1 \\
\hline IBA & - & 0.1 & 0.2 & 0.2 & 0.2 & - & 0.5 \\
\hline BAP & 2.5 & 2.0 & 1.5 & 1.0 & 0.5 & - & - \\
\hline$P G$ & - & - & - & - & 90 & - & - \\
\hline Ca.Pantothenate & - & - & - & - & 100 & - & - \\
\hline
\end{tabular}

IM, Initial Media; MM-1, MS medium-1; MM-2, MS medium-2; MM-3, MS medium-3; MM-4, MS medium-4; RM-1, MS rooting medium-1; RM2, MS rooting medium-2.

Laboratories, India. The media sterilization was done before adding growth hormones into it because they are heat sensitive.

\section{Inoculation of explants}

After sterilization of explants, they were inoculated in culture bottles aseptically and explants were transferred onto sterile paper with the help of sterile forceps for inoculation under aseptic conditions. The explants were further trimmed and extra outer leaves were removed to make them in suitable sizes $(2$ to $3 \mathrm{~cm}$ ). After cutting, explants were vertically inoculated into culture of $500 \mathrm{~mL}$ capacity bottles containing MS medium with $0.3 \mathrm{mgL}^{-1}$ of IAA and $3 \mathrm{mgL}^{-1}$ of BAP; then the bottles were tightly capped and properly sealed with wrap to avoid entry of external air. The bottles were transferred to growth chamber. All the cultures were kept in the culture room at $28 \pm 1^{\circ} \mathrm{C}$ and at photoperiod of $16 \mathrm{~h}$ provided by cool-white fluorescent light and the cultures were observed periodically. Only root cultures were maintained in darkness.

\section{Establishment of shoot cultures}

Explants of in vitro regenerated plantlets were used for proliferation of shoot cultures on the basal MS medium supplemented with kinetin $\left(0.5 \mathrm{mgL}^{-1}\right)$ and BAP $\left(1.0 \mathrm{mgL}^{-1}\right)$ in combination with NAA (0.1 or $\left.0.2 \mathrm{mgL}^{-1}\right)$ and with IAA $\left(0.1 \mathrm{mgL}^{-1}\right)$ and IBA $\left(0.2 \mathrm{mgL}^{-1}\right)$ for shoot amplification. Shoots were multiplied by repetitive transfer of original explants. Cluster of shoots amplified from initial lateral shoot explants were sub-cultured as it is without separation from the explants on the same regeneration media after one month from initial establishment stage multiplication of shoots were replicated 3 times with 10 explants per treatment. Multi shoots were divided into single micro shoots and transferred to fresh medium every 5 weeks of subculture. The data was recorded after 30 days of culture and only shoots greater than $2 \mathrm{~cm}$ were considered for taking data. The percentage of shoot induction, total number of shoots and length of shoots were recorded after 6 weeks of fifth, seventh, and eighth subcultures. The percentage of shoot induction was calculated as the total number of initial explants, which gave response to hormonal treatment per total number of explants multiplied by $100 \%$. After another 6 weeks of incubation, the proliferating cultures were transferred to different media for shoot elongation (Table 4).

\section{Establishment of root cultures}

The newly formed shoots were measured in the length of 2 to $3 \mathrm{~cm}$, 
excised individually from the parent explants and transferred to a rooting media. Two types of rooting medium were used; one is MS basal media with 3 types of hormones NAA, IAA, IBA and the other one is half strength MS media. The data was recorded after 30 days of culture.

\section{Acclimatization}

The crucial step of micro propagation is acclimatization of the in vitro obtained plantlets. In vitro regenerated plants of Aloe vera with no morphological abnormalities were transplanted into pots with a survival rate of $100 \%$. After 30 days, the micro propagated plantlets with well-developed roots were successfully acclimatized to ex vitro conditions. The pots $(8 \times 6 \mathrm{~cm})$ were kept ready for filling with garden soil, compost and sand in the proportion of $2: 1: 1$, respectively. The plants were then transplanted into the pots, then thoroughly watered and kept under plastic house having $80 \%$ humidity and $31^{\circ} \mathrm{C}$ temperature for 10 days. The plants were watered periodically and upper layer of the soil mulched occasionally whenever necessary, then the plants were shifted to shade house with less humidity and indirect sunlight. After 15 days, the plants were transferred to the soil. The micro propagated plants were morphologically uniform and grew well in the field. In the present study, about $100 \%$ of plantlets survived from tissue culture to the experimental plot, whereas Baksha et al. (2005) observed the survival rate of $70 \%$, Dwivedi et al. (2014) observed $83 \%$ survival for Indian Aloe and Liao et al. (2004) observed 93\% survival for Chinese Aloe.

\section{Statistical analysis}

The collected data were subjected to one way analysis of variance (ANOVA) carried out in different accessions of Aloe vera covering various parameters followed by Newman-Kuel's multiple comparisons test. The ANOVA revealed highly significant differences among various accessions for various characters. The results indicated the presence of adequate amount of genetic variability in the germplasm.

\section{RESULTS AND DISCUSSION}

\section{Morphological studies}

The evaluation and characterization of germplasm is prerequisite for any breeding programme aimed at improvement of yield. The qualitative as well as quantitative evaluation of germplasm is not only conducive in core collection, but also for its utilization in cultivation and breeding. The assessment of variability existing in the germplasm of accessions is of great interest for conservation of genetic resources and also for broadening of genetic base of species to be exploited by plant breeders. It helps in systematic cultivation of the plant for commercial purposes. The morphological studies for Aloe spp. are very essential characteristics for the medicinally and economically important genus to regularize the commercial and economical production.

In the present study, 12 Aloe accessions were studied and the morphological characteristics results are shown in Table 3. The result shows the occurrence of variation in morphological and biochemical characteristics when compared with the mother plants and their tissue culture generated plants. The extent of variation, however, differs from accession to accession. This could be related to differences in the genotypes of various accessions. Morphological analysis indicates that all the studied characteristics have a significant difference at $\mathrm{P}<0.01$ among Aloe accessions. Based on the morphology, the collection of accessions of Aloe vera germplasm has been divided into two morphotypes that are small Aloe vera (SAV) (plant size up to $40 \mathrm{~cm}$ ) and large Aloe vera (LAV) (plant size above $40 \mathrm{~cm}$ ). The LAV type of accessions shows the highest incidence. Accession IC111272(4), IC471883 (8), IC471882 (7), IC111267(1), and Aloe CIM-Sheetal (11) were found to be the tallest (61 to $67 \mathrm{~cm}$ range) as it possessed a distinct stem (calescent) with long inter nodes. Minimum leaf thickness $(18.1 \mathrm{~mm})$ for accession IC111271(3) and minimum wideness $(3.9 \mathrm{~cm})$ accession for local Aloe vera (12) was recorded. Leaf dry weight of local Aloe vera (12) was very low $(12.20 \mathrm{~g})$ and the highest $(23.7 \mathrm{~g})$ was in IC 111269 (2) among other accessions. Gel fresh weight was recorded as $58.52 \mathrm{ml} / 100 \mathrm{~g}$ in IC 111267 (1) with overall mean value of 20.025 as the highest and the lowest was $4.10 \mathrm{~g}$ in local Aloe vera (12) though the fresh gel weight was highest in IC 111267(1) and the dry gel weight was recorded as $12.80 \mathrm{~g}$ in IC111271 (3) as compared to all other accessions. Lowest aloine concentration recorded about was $0.86 \%$ from IC111267 (1), whereas the highest was $1.68 \%$ for accession IC111280 (6).

The medicinal and cosmetic value of the Aloe depends on the quantity of its biochemical constituents. Presently, an attempt has been made to evaluate the collected Aloe vera germplasm for its quality and yield components. The quality of the germplasm depends on the relative composition of leaves/leaflet. The plants producing higher amount of fresh gel, dry gel, biomass, presence of chemical compounds and lower amount of aloin are consider being of good quality. The accessions of IC111271, IC111269, IC111267 and Aloe CIM-Sheetal show better performance in vitro and in vivo than the local Aloe vera (wild) obtained from Hyderabad region. Among the present studies of Aloe accessions, the leaf yield per plant ranged between $0.652 \mathrm{~kg}$ and 23.2486 $\mathrm{kg} /$ plant and dry leaf weight between 12.20 and 23.70 $\mathrm{g} / \mathrm{kg}$. Accessions with high yield are IC111271, IC111269, IC111267 and Aloe CIM-Sheetal. The amount of gel (dry) obtained from one plant in one year is estimated to be 2.10 to $12.80 \mathrm{~g} / \mathrm{plant}$. High yield of gel can be obtained from accessions IC111271, IC111269 and Aloe CIM-Sheetal. Morphochemical evaluations can provide insight into the genetic structure and diversity within and among varieties from different geographical origins, producers and distributors. Without this information, there is no means of selecting appropriate plant material for the participation in screening programs with a view to introduce the novel varieties for industrial purpose (Radhamadhavi et al., 2012). 
Table 3. Morphological studies of Aloe accessions.

\begin{tabular}{|c|c|c|c|c|c|c|c|c|c|}
\hline Accession number & $\begin{array}{l}\text { Number of } \\
\text { leaves }\end{array}$ & $\begin{array}{l}\text { Number of } \\
\text { suckers/plant }\end{array}$ & $\begin{array}{l}\text { Peduncle } \\
\text { length }\end{array}$ & $\begin{array}{l}\text { Leaf } \\
\text { length } \\
\text { (cm) }\end{array}$ & $\begin{array}{l}\text { Leaf width } \\
\quad(\mathrm{cm})\end{array}$ & \multicolumn{2}{|c|}{$\begin{array}{l}\text { Stem length } \\
(\mathrm{cm})\end{array}$} & $\begin{array}{l}\text { Leaf weight } \\
\text { (g) }\end{array}$ & $\begin{array}{c}\text { Leaf } \\
\text { thickness } \\
(\mathrm{cm})\end{array}$ \\
\hline IC 111267 & $13.0 \pm 0.3^{b}$ & $3.0 \pm 0.2^{c}$ & $88.0 \pm 0.5^{\mathrm{h}}$ & $51.0 \pm 0.4^{b}$ & $4.0 \pm 0.06^{\mathrm{e}}$ & \multicolumn{2}{|c|}{$13.1 \pm 0.3^{\mathrm{a}}$} & $353.3 \pm 0.25^{j}$ & $22.1 \pm 0.04^{c}$ \\
\hline IC 111269 & $12.0 \pm 0.3^{c}$ & $1.0 \pm 0.1^{\mathrm{e}}$ & $124.0 \pm 0.6^{c}$ & $49.0 \pm 0.4^{c}$ & $4.8 \pm 0.03^{d}$ & \multicolumn{2}{|c|}{$10.3 \pm 0.2^{b}$} & $548.5 \pm 0.2^{c}$ & $31.6 \pm 0.04^{a}$ \\
\hline IC 111271 & $12.0 \pm 0.3^{c}$ & $5.0 \pm 0.04^{a}$ & $183.0 \pm 0.5^{\mathrm{a}}$ & $48.0 \pm 0.4^{\mathrm{bc}}$ & $5.2 \pm 0.05^{c}$ & \multicolumn{2}{|c|}{$11.3 \pm 0.2^{\mathrm{ab}}$} & $483.3 \pm 0.07^{d}$ & $18.1 \pm 0.06^{\mathrm{e}}$ \\
\hline IC 111272 & $15.3 \pm 0.1^{\mathrm{a}}$ & $1.0 \pm 0.1^{\mathrm{e}}$ & $118.0 \pm 0.6^{d}$ & $55.0 \pm 0.4^{\mathrm{a}}$ & $6.1 \pm 0.05^{a}$ & \multicolumn{2}{|c|}{$12.3 \pm 0.1^{\mathrm{a}}$} & $561.6 \pm 0.2^{b}$ & $18.8 \pm 0.06^{\mathrm{e}}$ \\
\hline IC 111279 & $12.0 \pm 0.3^{c}$ & $1.0 \pm 0.1^{\mathrm{e}}$ & $83.0 \pm 0.4^{\mathrm{hi}}$ & $49.0 \pm 0.3^{c}$ & $4.5 \pm 0.03^{\mathrm{de}}$ & \multicolumn{2}{|c|}{$10.6 \pm 0.04^{b}$} & $361.7 \pm 0.7^{i}$ & $20.3 \pm 0.1^{d}$ \\
\hline IC 111280 & $12.0 \pm 0.3^{c}$ & $4.0 \pm 0.04^{b}$ & $85.0 \pm 0.4^{i}$ & $51.0 \pm 0.3^{b}$ & $4.6 \pm 0.05^{\mathrm{de}}$ & \multicolumn{2}{|c|}{$8.5 \pm 0.06^{d}$} & $370.2 \pm 0.2^{h}$ & $19.5 \pm 0.04^{\mathrm{de}}$ \\
\hline IC471882 & $13.3 \pm 0.1^{b}$ & $4.0 \pm 0.04^{b}$ & $108.0 \pm 0.2^{f}$ & $51.0 \pm 0.4^{b}$ & $5.9 \pm 0.2^{\mathrm{ab}}$ & \multicolumn{2}{|c|}{$12.1 \pm 0.04^{\mathrm{a}}$} & $466.6 \pm 0.2^{f}$ & $18.5 \pm 0.04^{\mathrm{de}}$ \\
\hline IC471883 & $13.2 \pm 0.2^{b}$ & $2.0 \pm 0.05^{d}$ & $115.0 \pm 0.4^{\mathrm{e}}$ & $52.0 \pm 0.4^{\mathrm{ab}}$ & $5.8 \pm 0.05^{\mathrm{ab}}$ & \multicolumn{2}{|c|}{$12.4 \pm 0.06^{a}$} & $691.7 \pm 0.04^{\mathrm{a}}$ & $20.8 \pm 0.06^{d}$ \\
\hline IC471884 & $12.2 \pm 0.1^{c}$ & $2.0 \pm 0.05^{d}$ & $103.0 \pm 0.6^{g}$ & $48.0 \pm 0.2^{b c}$ & $6.1 \pm 0.05^{a}$ & \multicolumn{2}{|c|}{$12.7 \pm 0.06^{a}$} & $406.7 \pm 0.08^{g}$ & $22.3 \pm 0.05^{c}$ \\
\hline IC471885 & $11.1 \pm 0.1^{\mathrm{cd}}$ & $1.0 \pm 0.1^{\mathrm{e}}$ & $88.0 \pm 0.4^{h}$ & $48.0 \pm 0.2^{b c}$ & $5.2 \pm 0.05^{c}$ & 11 & $0.1^{\mathrm{ab}}$ & $333.3 \pm 0.1^{\mathrm{k}}$ & $25.3 \pm 0.06^{b}$ \\
\hline Aloe CIM-Sheetal (CAL-14) & $14.3 \pm 0.1^{\mathrm{ab}}$ & $5.0 \pm 0.05^{a}$ & $143.0 \pm 0.4^{b}$ & $49.0 \pm 0.2^{c}$ & $5.6 \pm 0.04^{b}$ & & $0.1^{a}$ & $471.6 \pm 0.02^{\mathrm{e}}$ & $21.6 \pm 0.09^{c}$ \\
\hline Wild Aloe vera (Local) & $10.2 \pm 0.1^{d}$ & $3.0 \pm 0.06^{c}$ & $78.0 \pm 0.4^{j}$ & $46.0 \pm 0.3^{d}$ & $3.9 \pm 0.05^{\mathrm{e}}$ & & $0.06^{\mathrm{c}}$ & $342.6 \pm 0.21$ & $20.3 \pm 0.05^{d}$ \\
\hline Accession number & Leaf dry weight (g) & $\begin{array}{r}\text { Gel fresh } \\
(\mathrm{g})\end{array}$ & ight & dry weight (g) & Biomass (g & ant) & Root & igth (cm) & $\begin{array}{c}\text { Aloin } \\
\text { concentration (\%) }\end{array}$ \\
\hline IC 111267 & $23.5 \pm 0.02^{\mathrm{a}}$ & $58.52 \pm$ & & $12.4 \pm 0.05^{\mathrm{a}}$ & $683.2 \pm 0$ & & & $\pm 0.1^{d}$ & $0.86 \pm 0.008^{\mathrm{e}}$ \\
\hline IC 111269 & $23.7 \pm 0.03^{a}$ & $56.27 \pm$ & & $12.4 \pm 0.05^{\mathrm{a}}$ & $713.2 \pm 0$ & & & $\pm 0.5^{\mathrm{e}}$ & $0.9 \pm 0.007^{\mathrm{e}}$ \\
\hline IC 111271 & $20.35 \pm 0.05^{b}$ & $49.98 \pm 0$ & & $12.8 \pm 0.03^{\mathrm{a}}$ & $720.8 \pm 0$ & & & $\pm 0.1^{\mathrm{b}}$ & $0.91 \pm 0.007^{\mathrm{e}}$ \\
\hline IC 111272 & $19.9 \pm 0.04^{b}$ & $20.7 \pm 0$ & & $8.5 \pm 0.01^{b}$ & $223.3 \pm 0$ & & 9.6 & $=0.07^{\text {ef }}$ & $1.15 \pm 0.005^{c}$ \\
\hline IC 111279 & $19.7 \pm 0.04^{b}$ & $15.12 \pm 0$ & & $6.3 \pm 0.04^{c}$ & $199.2 \pm 0$ & & 14. & $\pm 0.07^{d}$ & $1.4 \pm 0.007^{\mathrm{b}}$ \\
\hline IC 111280 & $15.8 \pm 0.02^{c}$ & $8.85 \pm 0$ & & $3.8 \pm 0.05^{d}$ & $123.2 \pm 0$ & & & $4 \pm 0.1^{d}$ & $1.68 \pm 0.001^{a}$ \\
\hline IC 471882 & $15.6 \pm 0.03^{c}$ & $6.3 \pm 0$. & & $3.4 \pm 0.02^{d}$ & $86.7 \pm 0$ & & & $5 \pm 0.2^{a}$ & $1.36 \pm 0.009^{b}$ \\
\hline IC 471883 & $12.64 \pm 0.01^{d}$ & $4.72 \pm 0$. & & $2.2 \pm 0.01^{\mathrm{e}}$ & $58.01 \pm 0$ & & 18. & $\pm 0.07^{\mathrm{C}}$ & $1.3 \pm 0.007^{b}$ \\
\hline IC 471884 & $12.81 \pm 0.03^{d}$ & $4.79 \pm$. & & $2.2 \pm 0.05^{\mathrm{e}}$ & $58.4 \pm 0$ & & & $2 \pm 0.1^{d}$ & $1.08 \pm 0.003^{c}$ \\
\hline IC 471885 & $13.8 \pm 0.08^{C}$ & $5.3 \pm 0.0$ & & $3.1 \pm 0.04^{d}$ & $74.4 \pm 0$ & & & $\pm 0.07^{\dagger}$ & $0.83 \pm 0.002^{d}$ \\
\hline Aloe CIM-Sheetal & $14.13 \pm 0.06^{c}$ & $5.65 \pm 0$ & & $3.2 \pm 0.04^{d}$ & $70.28 \pm c$ & & 27. & $\pm 0.07^{\mathrm{a}}$ & $0.78 \pm 0.004^{d}$ \\
\hline Wild Aloe vera (Local) & $12.2 \pm 0.09^{d}$ & $4.1 \pm 0$ & & $2.1 \pm 0.05^{\mathrm{e}}$ & $56.2 \pm 0$ & & & $t 0.04^{\text {ef }}$ & $1.2 \pm 0.007^{c}$ \\
\hline
\end{tabular}

Values are means + SE. Means followed by the same letter in a column are not significantly different $(p<0.05)$ by Newman-Kuel's multiple comparisons test.

\section{In vitro study}

In the in vitro study, the shoot initiation, shoot multiplication, rooting and hardening of plantlets for 12 accessions were studied. The surface sterilization process is an important step to avoid any type of endogenous and exogenous contaminants and also standardized media composition for the mass multiplication and fast growth of Aloe vera. In the present investigation, shoot tip was used as an explants cultured on MS supplemented medium with various concentrations 
Table 4. Effect of MS medium composition and Shoot proliferation response from shoot tips cultured on medium with different concentrations of growth regulators.

\begin{tabular}{clccc}
\hline $\mathbf{S} / \mathbf{N}$ & Growth regulator $\left(\mathrm{mgL}^{-1}\right)$ & Response (\%) & $\begin{array}{c}\text { Average number } \\
\text { of shoots/explant }\end{array}$ & $\begin{array}{c}\text { Average length } \\
\text { of shoots (cm) }\end{array}$ \\
\hline 1 & IAA+BAP $(0.3+3.00)$ & $18.79 \pm 0.01^{\mathrm{e}}$ & $3.80 \pm 0.05^{\mathrm{e}}$ & $2.60 \pm 0.05^{\mathrm{e}}$ \\
2 & IBA+IAA+NAA+BAP $(0.1+0.1+0.1+4.5)$ & $27.84 \pm 0.04^{\mathrm{d}}$ & $4.58 \pm 0.03^{\mathrm{c}}$ & $3.18 \pm 0.05^{\mathrm{c}}$ \\
3 & KIN+IBA+IAA+NAA+BAP $(0.5+0.2+0.1+0.2+1.5)$ & $87.89 \pm 0.02^{\mathrm{a}}$ & $8.84 \pm 0.03^{\mathrm{a}}$ & $4.89 \pm 0.03^{\mathrm{a}}$ \\
4 & KIN+IBA+IAA+NAA+BAP+GA $(0.5+0.2+0.1+0.2+1.5+0.5)$ & $77.34 \pm 0.08^{\mathrm{b}}$ & $6.71 \pm 0.07^{\mathrm{b}}$ & $3.56 \pm 0.02^{\mathrm{b}}$ \\
5 & KIN+IBA+IAA+NAA+BAP+GA $(0.5+0.2+0.1+0.2+1.5+1.0)$ & $65.68 \pm 0.05^{\mathrm{c}}$ & $4.23 \pm 0.03^{\mathrm{d}}$ & $2.88 \pm 0.01^{\mathrm{d}}$ \\
\hline
\end{tabular}

Multiplication of shoots was replicated three times with 10 explants per treatment. Values are means $\pm S E$. Means followed by the same letter in a column are not significantly different $(p \leq 0.05)$ by Newman-Kuel's multiple comparisons test.

and combinations. Establishment of aseptic cultures was difficult, but once a healthy culture was established, there was no further contamination. Under given conditions and over a culture of 60 days, explants from all the treatments produced multiple explants and roots simultaneously. In earlier studies, Aloe vera has been sterilized using the mercuric chloride which is harmful for environment. The method of the present study is easy and new for explants sterilization for in vitro culture of Aloe vera.

The ability of plant cell, tissue and organs to differentiate plants in culture has resulted in widespread applications in propagation and plant breeding. Conventional method of propagation in Aloe vera is through vegetative means (side buds) which is very slow. There is no viable seed setting in the plants. Aloe is exclusively a vegetatively propagated crop where young side branches are used as planting material. Single plant may produce 2 to 3 side shoots per year making availability of planting material in good quantity and quality, a problem.

Keeping the aforementioned things in mind, tissue culture studies were undertaken in the Aloe vera plants in this study. A number of protocols have been developed for micropropagation of Aloe plants using a variety of explants like shoot tip, axillary bud, stem cuttings, etc., by various researchers (Hosseini and Parsa, 2007). The method used for clonal propagation is also an important tool for raising pathogen free plants in culture (Walkey, 1980). Tissue cultures of $A$. barbadensis were established by Sanchez et al. (1988) using vegetative meristems and leaf explants. Shoot tips and auxillary buds are popular explants for micropropagation of Aloe (Aggarwal and Barna, 2004).

\section{Shoot initiation}

For in vitro clonal propagation of Aloe vera plants, shoot tips were used as explants. Explants were obtained from healthy parent plants of 12 accessions for micro propagation. After sterilization, shoot apices were directly inoculated into various media. These explants were inoculated in wide mouth culture bottles containing MS medium. The media was supplemented with different concentrations of BA alone or in combination with IBA or IAA. The explants cultured in combination of MS basal medium with BA, NAA, KIN and IBA started showing signs of proliferation after 15 days of culturing (Figure $2 \mathrm{a}$ to $f$ ). Best growth was observed on MS medium supplemented with $1.5 \mathrm{mgL}^{-1}$ BAP, $0.2 \mathrm{mgL}^{-1}$ IBA, 0.1 $\mathrm{mgL}^{-1} \mathrm{IAA}, 0.5 \mathrm{mgL}^{-1} \mathrm{KIN}$, and $0.5 \mathrm{mgL}^{-1} \mathrm{GA}_{3}$. New buds appeared from the axils of leaves of shoot explants and bud developed.

Cytokinin level produced a significant response upon the number of explants formed per plant and also showed influence on production of leaf numbers and rooting (Dwivedi et al., 2014). The shoot tip of explants initially produces 2 to 3 shoots within two weeks after inoculation. But in our method, 15 to 35 shoots/cultures were produced from single explant by subsequent 2 to 3 subcultures with the same medium which indicate the high efficiency of this protocol. The average length of shoots per culture was $4.89 \pm 0.03 \mathrm{~cm}$. Formation of the roots was best observed in Aloe CIM-Sheetal and IC111271 in the media containing MS basal media with 3 types of hormones NAA $0.2 \mathrm{mgL}^{-1}$, IAA $0.1 \mathrm{mgL}^{-1}$ and IBA $0.2 \mathrm{mgL}^{-1}$ within four weeks after inoculation for rooting. Proliferating shoots obtained from shoot tip explants of Aloe took maximum 6 to 7 weeks from the time of establishment to attain the size $(2$ to $3 \mathrm{~cm})$ suitable for rooting. The highest percentage of shoots that induced roots $(91.12 \%)$ was observed in MS medium supplemented with NAA $\left(0.2 \mathrm{mgL}^{-1}\right)$, IAA $\left(0.1 \mathrm{mgL}^{-1}\right)$ followed by IBA $\left(0.2 \mathrm{mgL}^{-1}\right)$.

\section{Shoot multiplication}

After initiation of the growth on the explants (30 days culturing), the newly formed shoots were excised individually with the help of sterilized blade and recultured on fresh bottles containing the same medium (MS medium with different supplements) to increase the number of shoots. The results obtained in the present study revealed that BAP at concentration of $1.5 \mathrm{mgL}^{-1}$ provides better shoot multiplication. All the cultures 

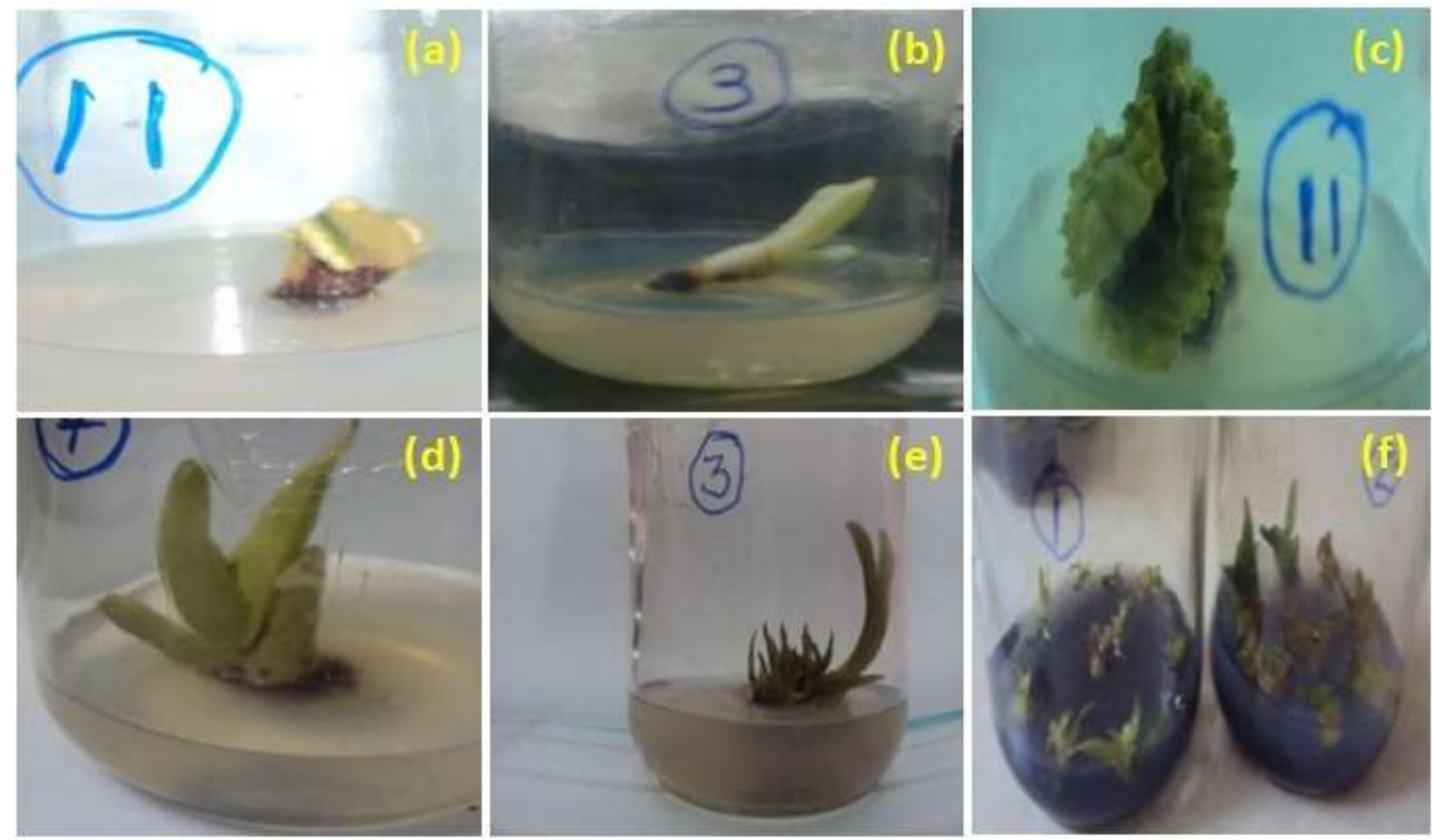

Figure 2. (a) Shoot tip regeneration in 1st week- Aloe CIM-Sheetal (11). (b) Shoot tip regeneration in 1st week-accession IC111271(3). (c) 30 Days regenerated shoot tip of accession IC471882 (7). (d) Regeneration of multiple shoots in Aloe CIM Sheetal (11). (e) Multiple shoots in early stage before subculture in IC111271(3). (f) Sub cultured shoot tips in IC111267(1) and IC111269(2).

showed shoot proliferation on MS medium with different concentrations. On an average, each explants produced 5 to 8 shoots (Figure 3a to I).

The results show that accessions Aloe CIM-Sheetal (Tag no:11), IC 111271 (3), IC 111279 (5), and IC111269 (2) are high potential accessions, IC 471882 (7), IC111267 (1), IC471885 (10) have shown moderate proliferation and IC 111280 (6), IC111280 (8), IC471884 (9), and wild Aloe vera (12) showed poor shoot proliferation and rooting among all accessions for their multiplication ratio of axillary buds, multiple shoots/clumps, and roots were regenerated after sub culturing. Cytokinins are one of the most important growth regulators affecting the shoot proliferation (Garland and Stolz, 1981). A range of cytokinins BA, kinetin and 2-ip have been used in micropropagation (Bhojwani and Razdan, 1992). BA variations affecting shoot proliferation were also reported by Bhandari et al. (2010), Gantait et al. (2010), Mangal (2009), and Chaudhuri and Mukundan (2001) also reported the use of $\mathrm{BA}$ in shoot proliferation of Aloe polyphylla and A. vera, respectively. Some researchers have shown that the presence of both auxin and cytokinin is necessary for shoot proliferation (Rout et al., 2001).
An interesting result was observed in explants preparation, sizing and a single mother plant can be multiplied for 30 to 35 explants per mother plant and 8.84 \pm 0.03 shoots per explants were obtained on MS medium supplemented with BAP $\left(1.5 \mathrm{mgL}^{-1}\right)$, KIN $\left(0.5 \mathrm{mgL}^{-1}\right)$, NAA $\left(0.2 \mathrm{mgL}^{-1}\right)$, IAA $\left(0.1 \mathrm{mgL}^{-1}\right)$, and IBA $\left(0.2 \mathrm{mgL}^{-1}\right)$ in 7 weeks, in comparison with 30 shots from 18 explants obtained from 18 mother plants in 8 weeks and 20 shoots per plant in 8 weeks was reported (Balraj and Neelu, 2009). It was also reported that the enhancement of shoots was observed by using BA and NAA. The clusters of shoots were separated into pieces and each was subcultured individually on the same medium periodically. After third subculture, the shoot multiplication rate remained constant. On the other hand, regeneration of shoot buds was moderate (65 to $77 \%$ ) on a medium containing: $1.5 \mathrm{mgL}^{-1} \mathrm{BAP}, 0.5 \mathrm{mgL}^{-1}$ kinetin, $0.2 \mathrm{mgL}^{-1}$ of IBA, $0.1 \mathrm{mgL}^{-1}$ of IAA, $0.2 \mathrm{mgL}^{-1}$ of $\mathrm{NAA}$, and $1.5 \mathrm{mgL}^{-1}$ BAP, $0.5 \mathrm{mgL}^{-1}$ kinetin, $0.2 \mathrm{mgL}^{-1}$ of IBA, $0.1 \mathrm{mgL}^{-1}$ of IAA, $0.2 \mathrm{mgL}^{-1}$ of NAA and $1.0 \mathrm{mgL}^{-1}$ of $\mathrm{GA}_{3}$, respectively. Comparatively, the lowest number of 18 to $28 \%$ adventitious shoots were observed in the medium containing $0.3 \mathrm{mgL}^{-1}$ of IAA, $3.0 \mathrm{mgL}^{-1}$ of BAP (IM) and $0.1 \mathrm{mgL}^{-1} \mathrm{NAA}, 0.1 \mathrm{mgL}^{-1}$ of IBA, $0.1 \mathrm{mgL}^{-1}$ of IAA, and 

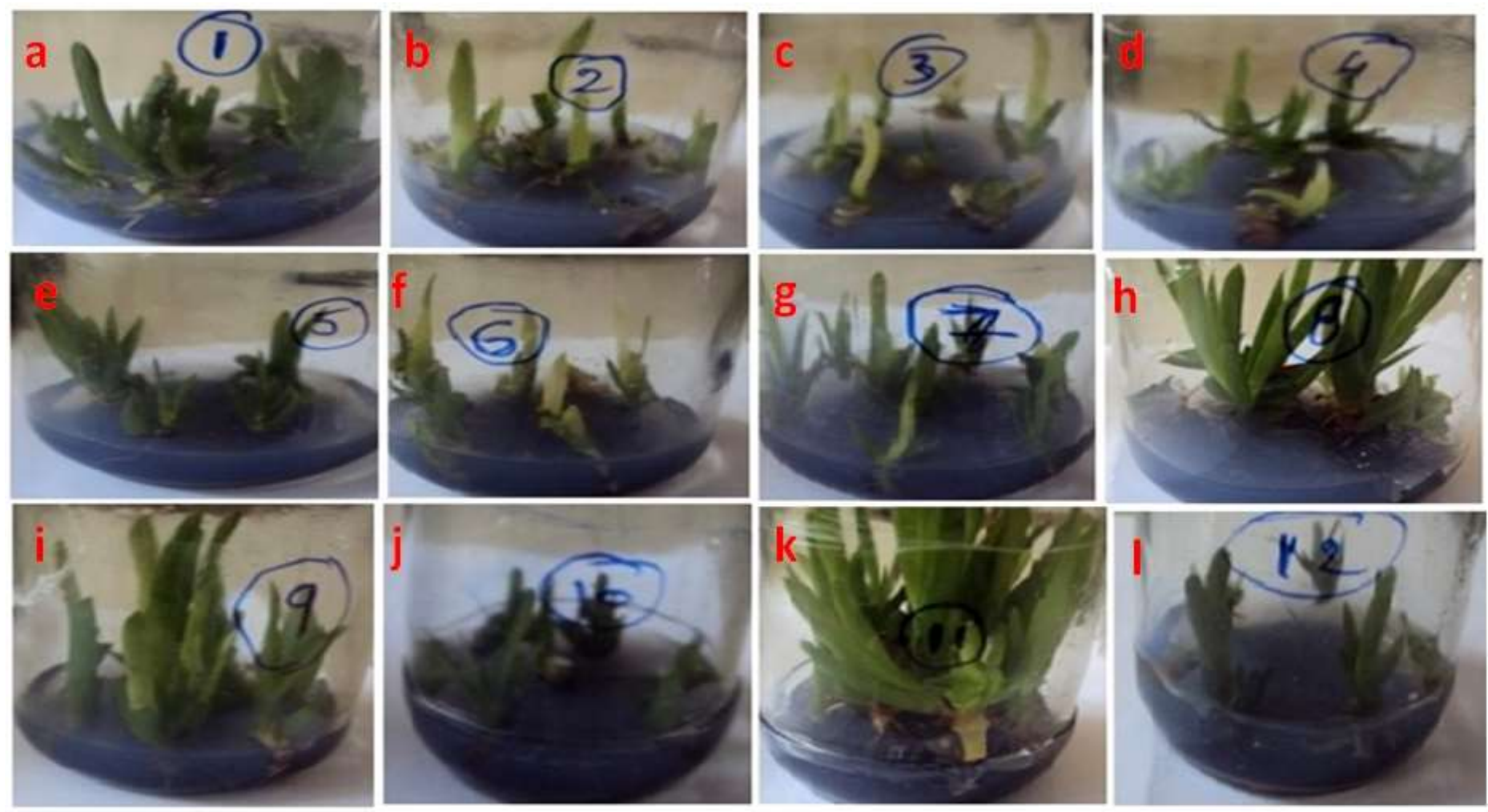

Figure 3. Regeneration of multiple shoots on MS medium of 12 accessions. (a) IC111267. (b) IC111269. (c) IC111271. (d) IC111272. (e) IC111279. (f) IC111280. (g) IC471882. (h) IC471883. (i) IC471884. (j) IC471885. (k) Aloe CIM-Sheetal (CAL14). (I) wild Aloe vera (local).

$4.5 \mathrm{mgL}^{-1} \mathrm{BAP}$. The highest concentration of $4.5 \mathrm{mgL}^{-1}$ of BAP did not increase shoot proliferation. It was also reported that the highest shoot proliferation in $A$. vera was found in MS medium containing BA and IBA (Mukesh et al., 2011), where better proliferation occurred on medium containing kinetin instead of BA (Dwivedi, 2014). NAA and IBA are the most commonly used for root induction (Bhojwani and Razdan, 1992). Effect of 0.1 $\mathrm{mgL}^{-1}$ of NAA, $0.5 \mathrm{mgL}^{-1}$ of IAA, and $0.5 \mathrm{mgL}^{-1}$ of IBA on MS medium in rooting showed poor response.

For shoot proliferation, growth regulators especially cytokinins (Bhojwani, 1980) are one of the most important factors affecting the response. A range of cytokinin (kinetin, BA, 2-ip and Zeatin) has been used in micro propagation of work. Studies conducted by different researchers have clearly shown that $B A$ is a more effective, reliable and useful cytokinin for shoot proliferation in Aloe vera (Debiasi et al., 2007). IBA (Chaudhuri and Mukundan, 2001) and acetic acid (Mukherjee and Roy, 2008) were also reported to be helpful in shoot proliferation in Aloe. Meyer and Staden (1991) reported auxillary shoot formation using IBA, whereas Roy and Sarkar (1991) obtained shoot on medium containing 2, 4-D with Kinetin. Richwine et al. (1995) reported induction of shoots using Zeatin. Liao et al. (2004) reported that the best medium for micro propagation of Aloe vera was $\mathrm{MS}+2 \mathrm{mgL}^{-1} \mathrm{BA}+0.3$
$\mathrm{mgL}^{-1}$ NAA. Budhiani (2001) demonstrated that the best initiation and multiplication of shoot was on MS medium supplemented with $0.2 \mathrm{mgL}^{-1} \mathrm{BAP}+0.002 \mathrm{mgL}^{-1} \mathrm{NAA}$ and $2 \mathrm{mgL}^{-1} \mathrm{BAP}+0.002 \mathrm{mgL}^{-1} \mathrm{NAA}$, respectively. Hashemabadi and Kaviani (2008) reported that MS with $0.5 \mathrm{mgL}^{-1} \mathrm{BA}$ and $0.5 \mathrm{mgL}^{-1} \mathrm{NAA}$ produced the highest number of shoots. According to Liu (2001), the best medium for shoot proliferation is MS with $\mathrm{BA}\left(1.0 \mathrm{mgL}^{-1}\right)$ and IBA $\left(0.3 \mathrm{mgL}^{-1}\right)$. Best medium for bud initiation according to Liao et al. (2004) is MS with $2.0 \mathrm{mgL}^{-1} \mathrm{BA}+$ $0.3 \mathrm{mgL}^{-1} \mathrm{NAA}$ with $30 \mathrm{gL}^{-1}$ sucrose $+0.6 \mathrm{gL}^{-1} \mathrm{PVP}(\mathrm{pH}$ 5.8). Hirimburegama and Gamage (1995) cultured the plant on MS medium supplemented with $0.18 \mathrm{mgL}^{-1}$ IAA and $2.25 \mathrm{mgL}^{-1}$ BA. Zhou et al. (1999) suggested MS + 6 BAP $\left(3 \mathrm{mgL}^{-1}\right)$ as the best medium for the induction of buds. Also, in the present study, shoot proliferation occurred in the presence of cytokinin. The different phytohormonal combinations of BAP proved to be more effective. MS medium supplemented with $1.5 \mathrm{mgL}^{-1} \mathrm{BAP}$ $+0.2 \mathrm{mgL}^{-1} \mathrm{IBA}+0.5 \mathrm{mgL}^{-1} \mathrm{KIN}+0.1 \mathrm{mgL}^{-1} \mathrm{IAA}+0.2$ $\mathrm{mgL}^{-1} \mathrm{NAA}+0.5 \mathrm{mgL}^{-1} \mathrm{GA}_{3}$ gave (77 to $88 \%$ ) best shoot proliferation/multiplication. This is in contrast with earlier work by Meyer and Staden (1991) who reported better proliferation in Aloe vera on medium containing kinetin instead of BA. This difference may be due to the difference in the genotype of plant used (Abrie and Staden, 2001). 

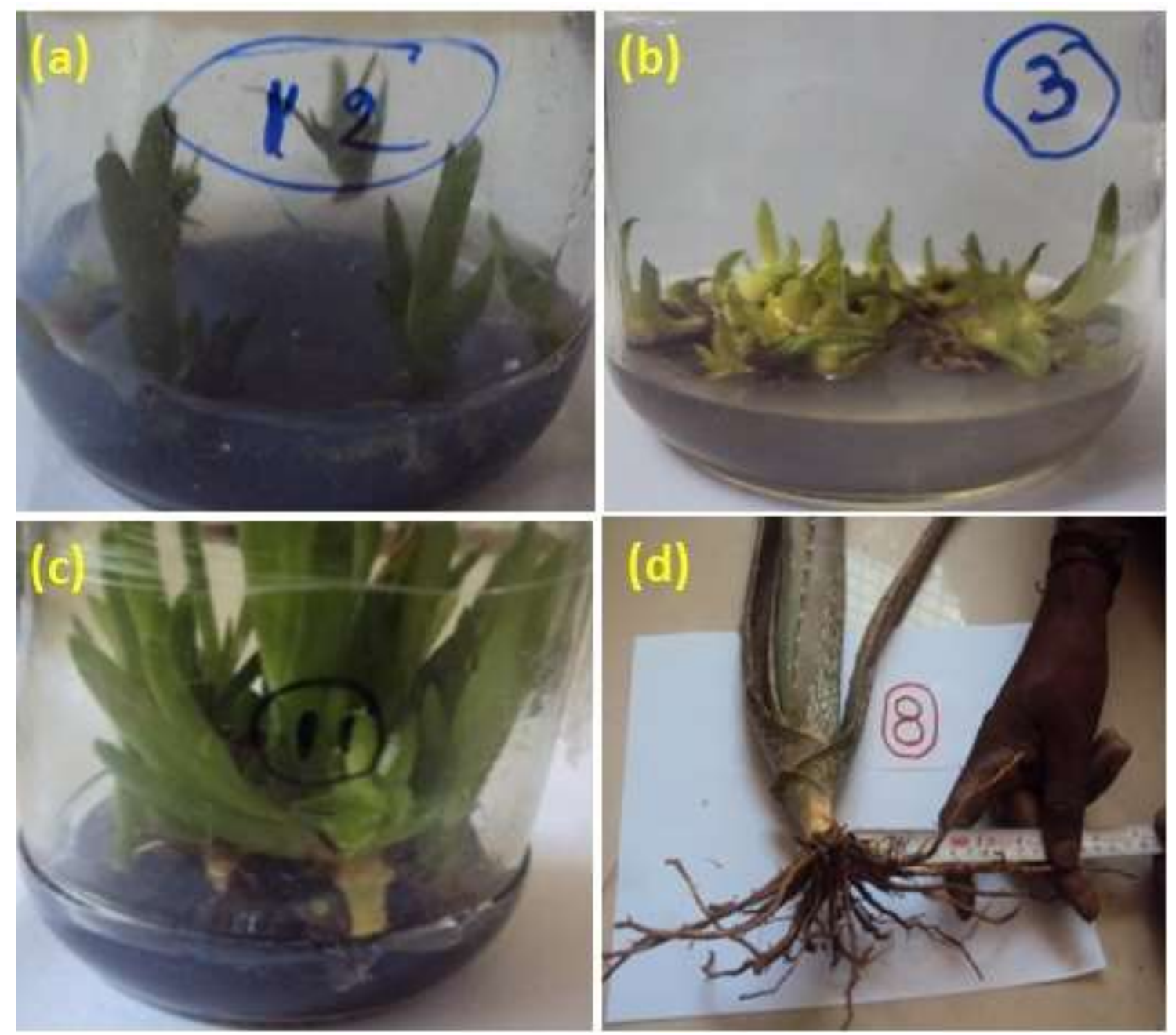

Figure 4. Shoot proliferation of various aloe accession on MS medium: (a) Regeneration of multiple shoots on $\mathrm{MS}+1.0 \mathrm{mgL}^{-1} \mathrm{BAP}+0.5 \mathrm{mgL}^{-1} \mathrm{KIN}+0.2 \mathrm{mgL}^{-1} \mathrm{NAA}+0.1 \mathrm{mgL}^{-1} \mathrm{IAA}$ and $0.2 \mathrm{mgL}^{-1} \mathrm{IBA}$ in accession wild Aloe vera (12); (b) Multiple shoot regeneration after subculture of IC111271(3); (c) Root induction on $\mathrm{MS}+0.2 \mathrm{mgL}^{-1}$ $\mathrm{NAA}+0.1 \mathrm{mgL}^{-1} \mathrm{IAA}+0.2 \mathrm{mg}$ IBA of Aloe CIM Sheetal (11); (d) Measurement of hardened plantlet root length of accession IC471883 (8).

\section{Rooting}

The in vitro raised 3 to $4 \mathrm{~cm}$ long shoots were excised individually from the proliferated shoot clumps and cultured on rooting media where MS medium was supplemented with different concentrations of NAA. All the combinations showed induction of roots. Maximum number of roots (2 to 7 ) per plant was obtained in plantlets cultured on MS $+0.2 \mathrm{mgL}^{-1}$ of NAA. The plantlets cultured on MS medium supplemented with 2 to $10 \mathrm{mgL}^{-1}$ NAA showed induction of only one root per shoot. The roots obtained were creamish yellow in color and with/without branching. Newly formed micro roots measuring 2 to $3 \mathrm{~cm}$ in length (Figure $4 a$ to d) were excised individually from the parent explants and transferred to rooting media. Two types of rooting media were used; one is MS basal media with 3 types of hormones NAA, IAA, IBA and other half strength MS media (Table 5). Data were recorded after 30 days of culture.

The highest root response in $A$. vera was reported in hormone free medium (Bhandari et al., 2010). In the current study, healthy rooting was observed in NAA $(0.2$ $\left.\mathrm{mgL}^{-1}\right)$ and IBA (0.2 $\left.\mathrm{mgL}^{-1}\right)$ medium. Healthy roots (number $>7$ and length $>3 \mathrm{~cm}$ ) were obtained in 8 weeks of time. Hardening is an important step in tissue culture. Rooting response of micro shoots is reported to be controlled by growth regulators in the medium (Abrie and Staden, 2001), basal salt composition (Garland and Stoltz, 1981), genotype (Rines and McCoy, 1981) as well as cultural conditions. NAA and IBA are the most commonly used auxins for root induction (Bhojwani and 
Table 5. Effect of auxins on rooting of Aloe vera shoots after 6 weeks of In vitro culture.

\begin{tabular}{lccc}
\hline $\begin{array}{l}\text { Conc. of growth regulators } \\
\left(\mathbf{m g L}^{-1}\right) \text { in }\end{array}$ MS medium & $\begin{array}{c}\text { percentage of shoots } \\
\text { showing root formation }\end{array}$ & $\begin{array}{c}\text { Average number of roots } \\
\text { per shoot (mean } \pm \text { SE) }\end{array}$ & $\begin{array}{c}\text { Average length of root (cm) } \\
\text { per shoot (mean } \pm \text { SE) }\end{array}$ \\
\hline 0.1 NAA & $65.57 \pm 0.05^{\mathrm{d}}$ & $4.98 \pm 0.005^{\mathrm{d}}$ & $2.09 \pm 0.03^{\mathrm{c}}$ \\
$0.2 \mathrm{NAA}$ & $91.12 \pm 0.05^{\mathrm{a}}$ & $6.89 \pm 0.007^{\mathrm{a}}$ & $3.08 \pm 0.04^{\mathrm{a}}$ \\
$0.5 \mathrm{NAA}$ & $79.87 \pm 0.3^{\mathrm{b}}$ & $6.15 \pm 0.005^{\mathrm{b}}$ & $2.97 \pm 0.005^{\mathrm{b}}$ \\
0.1 IBA & $49.83 \pm 0.2^{\mathrm{e}}$ & $2.98 \pm 0.003^{\dagger}$ & $1.88 \pm 0.005^{\mathrm{d}}$ \\
0.2 IBA & $74.93 \pm 0.03^{\mathrm{c}}$ & $5.51 \pm 0.003^{\mathrm{c}}$ & $2.91 \pm 0.005^{\mathrm{b}}$ \\
0.5 IBA & $40.64 \pm 0.07^{\dagger}$ & $2.75 \pm 0.008^{\mathrm{g}}$ & $2.04 \pm 0.05^{\mathrm{c}}$ \\
0.1 IAA & $33.65 \pm 0.05^{\mathrm{g}}$ & $3.65 \pm 0.005^{\mathrm{e}}$ & $0.97 \pm 0.003^{\mathrm{e}}$ \\
0.2 IAA & $26.72 \pm 0.08^{\mathrm{h}}$ & $1.31 \pm 0.007^{\mathrm{h}}$ & $0.84 \pm 0.005^{\dagger}$ \\
0.5 IAA & - & - & - \\
\hline
\end{tabular}

The experiment was replicated two times with 10 explants per treatment. Values are means \pm SE. Mean values followed by the same letter in a column are not significantly different $(p \leq 0.05)$ by Newman-Kuel's multiple comparisons test.

Razdani, 1992). By use of IBA, many plants such as Lycoperscicon esculentum (Sibi, 1982), Hedychium roxburgii (Tripathi and Bitaillion, 1995) and Carnation (Werker and Leshem, 1987) gave in vitro rooting. Rooting was achieved on MS medium $+0.18 \mathrm{mgL}^{-1} \mathrm{NAA}+0.226$ $\mathrm{mgL}^{-1} \mathrm{BA}$ (Hirimburegama and Gamage, 1995). Zhou et al. (1999) used supplements NAA $\left(0.3 \mathrm{mgL}^{-1}\right)$ and IBA $\left(0.3 \mathrm{mgL}^{-1}\right)$ for rooting and found that NAA was better than IBA in the average number of roots produced and rooting rate. Best rooting was observed by Liao et al. (2004) by using $1 / 2 \mathrm{MS}+0.2$ mg NAA.

The shoot tips subjected to MS medium supplemented with different concentration of NAA were also examined. Maximum rooting was observed in $\mathrm{MS}+0.2 \mathrm{mgL}^{-1} \mathrm{NAA}+$ $0.2 \mathrm{mgL}^{-1} \mathrm{IBA}+0.1 \mathrm{mgL}^{-1} \mathrm{IAA}$. These results are in agreement with the results of Zhou et al. (1999). However, Natali et al. (1990), Meyer and Staden (1991), and Richwine et al. (1995) reported rooting in hormone free medium. In the present study, no rooting was obtained in hormone free medium even on prolonged waiting.

Regeneration of plants from callus may help to induce variability in the Aloe germplasm for future improvement. Over the last years, a number of micropropagation protocols have been developed using a variety of explants like shoot tips (Hashemabadi and Kaviani, 2008), auxillary buds (Hirimburegama and Gamage, 1995), stem cutting and leaf explants and plant regeneration via callus formation in $A$. barbadensis which occurs at low frequency (Sanchez et al., 1988). Successful establishment of calli and subsequent plantlet regeneration is reported in Aloe pretoriensis (Groenewald et al., 1975), Aloe saponaria (Yagi et al., 1983) and $A$. vera (Gui et al., 1990; Roy and Sarkar, 1991). Racchi (1987) used MS medium supplemented with $0.5 \mathrm{mgL}^{-1}$ 2,4-D and $1 \mathrm{mgL}^{-1}$ kinetin for root explants and $0.2 \mathrm{mgL}^{-1}$ 2,4-D and $1 \mathrm{mgL}^{-1}$ kinetin for leaf meristems. In $A$. saponaria, the best results were obtained using root tissue with a combination of $1 \mathrm{ppm}$ indoleacetic acid (IAA) and 0.5 ppm 2,4-D and 2 ppm kinetin (Yagi et al., 1983). However, the occurrence of plant regeneration from these calli was not reported. Gui et al. (1990) used stem segments of $A$. vera on MS medium with different hormones and successfully regenerated a large number of plantlets via callus. The best results were obtained on the medium with zeatin $2 \mathrm{ppm}+0.5 \mathrm{ppm}$ NAA. Roy and Sarkar (1991) reported that MS basal medium supplemented with $1 \mathrm{mgL}^{-1}$ 2,4-D and $0.2 \mathrm{mgL}^{-1}$ kinetin gave the best callus induction. $A$. vera has a great future for tissue engineering applications, because it is a unique plant and appealing for physicochemical and biological properties (Shekh et al., 2017).

The shoot tips were used as explants, cultured on different combinations of auxins and cytokinins and were examined. Among all the combinations, no response was observed in $\mathrm{MS}$ basal medium with 2, 4-D $\left(0.5 \mathrm{mgL}^{-1}\right)$ and kinetin $\left(0.2 \mathrm{mgL}^{-1}\right)$. It was also revealed that regenerated plants were morphologically similar to the mother (control) plant and that the method of micropropagation used in this investigation (axillary bud method) does not usually produce some clones. The result of acclimatization showed that $100 \%$ of plantlets survived and grew under greenhouse conditions and were morphologically similar to mother plants. The leaves also started thickening in shade house.

The tissue culture plants were hardened and these plants could face ambient environmental conditions (Bhojwani and Razdan, 1992). Rooted plantlets were transferred from culture bottles to plastic pots containing 1:1 ratio of soil: rice husk. Natali et al. (1990) suggested the mixture of soil, sand and perlite. While Aggarwal and Barna (2004) suggested mixture of soil and farmyard manure, and Hashemabadi and Kaviani (2008) suggested the mixture of cocopeat and perlite. There is decrease in the glycoprotein, verectin (Yagi et al., 2000) and barbaloin content in the clonally regenerated plants of $A$. vera. According to Yagi et al. (2006), the clonally induced mutations are associated with the phenotypic 

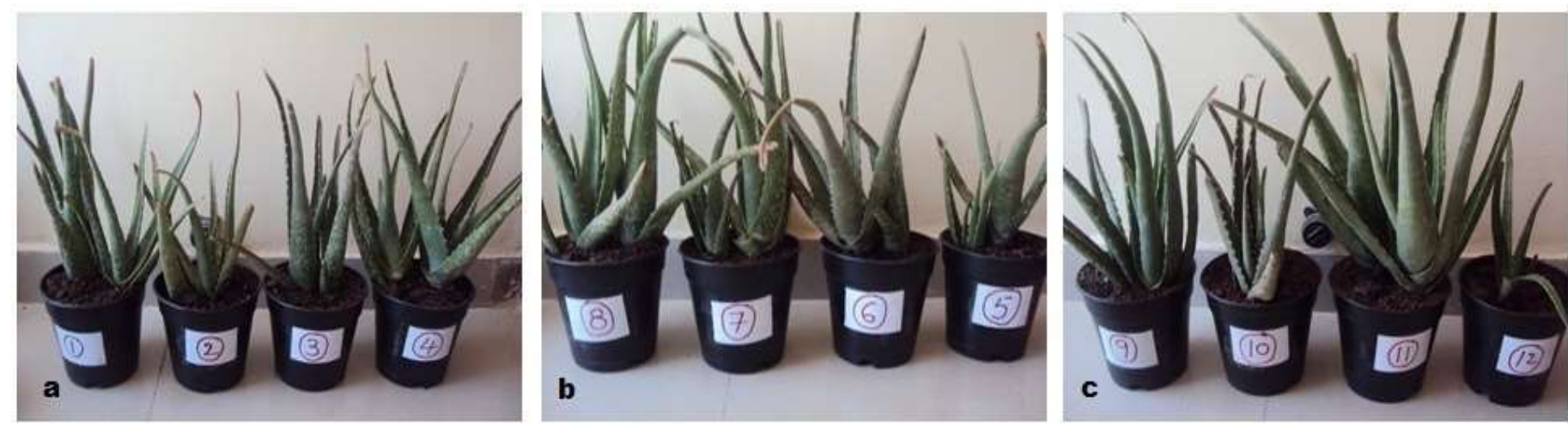

Figure 5. (a-c) Hardened plantlets of twelve accessions transferred to soil in bigger pots: (1) IC111267, (2) IC111269, (3) IC111271, (4) IC111272, (5) IC111279, (6) IC111280, (7) IC471882, (8) IC471883, (9) IC471884, (10) IC471885, (11) Aloe CIM-Sheetal (CAL14), (12) wild Aloe vera (local).

variation observed in $A$. vera. The present results show the occurrence of variation in morphological and biochemical characteristics when compared with the mother plants and their tissue culture generated plants. The extent of variation, however, differs from accession to accession. This could be related to differences in the genotypes of various accessions.

\section{Hardening of plantlets}

After 30 days of culture on rooting media, the plantlets were successfully acclimatized. The pots $(8 \times 6 \mathrm{~cm})$ were kept and readily filled with garden soil, compost and sand in the proportion of $2: 1: 1$, respectively. The plants were then transplanted into the pots, then thoroughly watered and kept under plastic house having $80 \%$ humidity and $31^{\circ} \mathrm{C}$ temperature for ten days. Then the plants were shifted to shade house with less humidity and indirect sunlight. After 15 days, the hardened plantlets were transferred to the soil. The result of acclimatization showed that $100 \%$ of plantlets survived to grow under greenhouse conditions and were morphologically similar to mother plants (Figure $5 \mathrm{a}$ to $\mathrm{c}$ ). The plants were watered periodically and upper layer of the soil mulched occasionally whenever necessary. The overall procedure of micro propagation flow diagram is as shown in Figure 6 . The tissue culture showed the rapid production of large number of true type plants. Somaclonal variations are therefore undesirable. However, in the present case, the somaclonal variants can be a valuable source of genetic variation in the germplasm. The somaclonal variants thus obtained need detailed genetic characterization before being put to use. Genetic variation is an essential component of any conventional breeding programme. Aloe germplasm lacks natural genetic recombination mechanism due to the absence of sexual reproduction. The tissue culture technology has great potential for induction of genetic variability.

\section{Conclusion}

The plant of $A$. vera shows slight morphological differences in stems and leaf length, but as they had been collected from different areas which have different environmental conditions, these changes are exceptional since all the accessions collected from different places were cytologically diploid with chromosome number $2 n=14$ and maintained in the same environmental conditions at Indian Immunologicals Ltd, Hyderabad. It was observed that variability can be related to genetic makeup/genetic diversity. Each explant gave rise to 8.84 shoots in 7 weeks and total number of 15 to 35 shoots/cultures was produced from single explants. Formation of the roots was observed best in Aloe CIMSheetal and IC111271 within four weeks after inoculation of rooting. The concentration of MS media played a significant role in shoot initiation, proliferation, rooting and regeneration of plant; this depends on the genotypic variation of the explants and is reinforced by the suitable cultural and environmental conditions. This study standardized the surface sterilization procedure and less expensive media composition with high-frequency regeneration as well as for conservation of an important miracle medicinal plant of $A$. vera. So, this protocol has been proven to potentially save the high yielding species from extinction and facilitates germplasm conservation, considering its safer sterilization method and efficient plant in vitro propagation system. It would be interesting to collect $A$. vera accessions from different regions and compare the morphological as well as tissue culture results together and this study will be useful for conservation of endangered Aloe spp.

\section{CONFLICT OF INTERESTS}

The authors have not declared any conflict of interests. 


\section{Excised explants taken from the mother plant are treated to eliminate microbes}

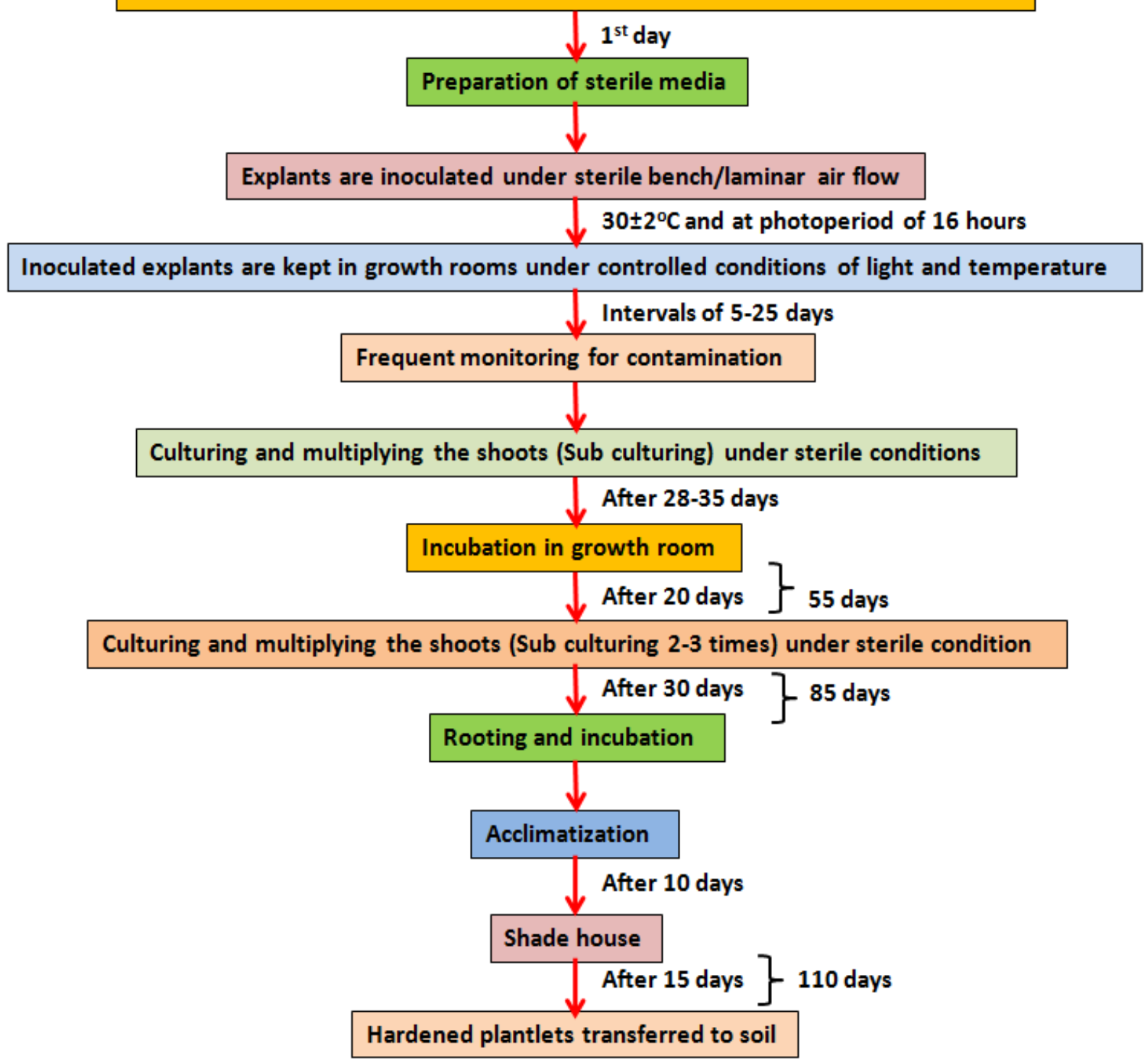

Figure 6. Flow diagram showing the overall procedure of in vitro culture of Aloe barbadensis Mill.

\section{ACKNOWLEDGEMENTS}

The authors profusely thank the Department of Genetics and Biotechnology, Osmania University, Hyderabad, India, for funding the research work. They would like to thank Dr. Vandana Tyagi, Principal Scientist, National Bureau of Plant Genetic Resources (NBPGR) New Delhi, India and Director, Central Institute of Medicinal and Aromatic Plants (CIMAP) Research Center, Boduppal, Hyderabad, Telangana, India for this study.

\section{REFERENCES}

Abrie AL, Staden JV (2001). Micro propagation of endangered Aloe polyphylla. J. Plant Growth Regulation. 33:19-23.
Aggarwal D, Barna KS (2004). Tissue culture propagation of elite plant of Aloe vera (L.) J. Plant Biochem. Biotechnol. 13:77-79.

Ahmed S, Kabir AH (2007). Development of Rapid Micro propagation Method of Aloe vera L. Sjemenarstvo. 24:121-128.

Albanyl NJ, Vilche S, Lion MM, Chacin P (2006). A methodology for the propagation in edge Aloe vera. Rev. Fac. Agron. 23:213-222.

Baksh R, Jahan MA, Khatun R, Munshi JL (2005). Micropropagation of Aloe barbadensis Mill through in vitro culture of shoot tip explants. Plant Tissue Cult. Biotech. pp. 121-126.

Balraj Singh, Neelu Sood (2009). Significance of explants preparation and sizing in Aloe vera (L.). A highly efficient method for in vitro multiple shoots induction. Scientia Horticulturae. 122:146-151.

Bhandari, Aravind Kumar, Negi, JS, Bisht VK, Bharti MK (2010). In vitro propagation of Aloe vera - A plant with Medicinal properties. Nat. Sci. 8:8

Bhojwani SS (1980). In vitro propagation of garlic by shoot proliferation. Sci. Hortic. 13:47-52.

Bhojwani SS, Razdan MK (1992). Plant Tissue Culture Theory and 
Practice. Elsevier, Amsterdam, London, New York, Tokyo Biol. Sci. 39:1, 1 - 9

Budhiani E (2001). Micropropagation of Aloe vera through shoot multiplication. Ph.D. Thesis. Indonesia DLN Institute. Indonesia.

Campestrini LH, Kuhnen S, Lemos PMM, Bach DB, Dia PF, Maraschin M (2006). Cloning protocol of Aloe vera as a studycase for "Tailor-Made" Biotechnology to small farmers. J. Technol Manag Innov. 1(5):76-79.

Chandra Sekhar SB, Rama Rao B, Adhrvana Chari M, Chakrapani P, Latha T, Venkatesh K, Arun Jyothi B, Amareswari P, Roja Rani A (2013). Cultivation, Phytochemical studies, Biological activities and Medicinal uses of Aloe ferox grand father of aloes an important medicinal plant. Int. J. Pharmacol. 9(7):405-415.

Chaudhuri S, Mukundan U (2001). Aloe vera (L.) micropropagation and characterization of its gel. Phytomorphol. 51(2):155-157.

Debiasi C, Silva C, Pescador R (2007). Micropropagation of Aloe vera L. Revista Brasileira De Plantas Medicinais. 9:36-43.

Dwivedi NK, Indiradevi A, Asha KI, Asokan Nair R, Suma A (2014). A protocol for micro propagation of Aloe vera L. (Indian Aloe) - a miracle plant. Res. Biotechnol. 5(1):1-5.

Gantait S, Mandal N, Bhattacharya S, Das PK (2010). A Novel Strategy for in vitro conservation of Aloe vera L. through long term shoot culture. Biotechnology 9(3):326-331.

Garland P, Stoltz LP (1981). Micropropagation of Pissrdi plum. Ann Bot. 48:387-389.

Gui YL, Xu TY, Gu SR, Liu SQ, Zhang Z, Sun GD, Zhang Q (1990). Studies on stem tissue culture and organogenesis of Aloe vera. Acta Bot Sini. 32(8):606-610.

Groenewald EG, Koeleman A, Wessels DCJ (1975). Callus formation and plant regeneration from seed tissue of Aloe pretoriensis. Zeitschrift für Pflanzenphysiologie, 75(3), 270-272.

Hashemabadi D, Kaviani B (2008). Rapid micro-propragation of Aloe vera L. via shoot multiplication. Afr. J. Biotechnol. 7(12):18991902.

Hirimburegama K, Gamage N (1995). In vitro multiplication of Aloe vera meristem tips for mass propagation. Hort. Sci. 27: 15-18.

Hosseini R, Parsa M (2007). Micropropagation of Aloe vera L. grown in South Iran. Pakis J. Biol. Sci. 10 (7):1134-1137.

Liao Z, Chen M, Tan F, Sun X, Tang K (2004). Micro propagation of endangered Chinese Aloe. Plant Cell Tiss. Org. Culture. 76(1):8386.

Mangal Singh Rathore MS, Panvar D, Rathore JSH, Dagla R, Shekhawat NS (2009). Micropropagation of selected genotypes of Aloe vera (L) An ancient plant for modern Industry. J. Sustain. For. 28:935-950.

Meyer HT, Staden JV (1991). Rapid in vitro propagation of Aloe barbadensis Mill. Plant Cell Tissue Organ Cult. 26:171-176.

Mukesh Kumar, Sumer Singh, Satyapal Singh (2011). In vitro Morphogenesis of a medicinal plant - Aloe vera L. Asian J. Plant Sci. Res. 1(1):31-40.

Mukherjee A, Roy Chowdhury B (2008). The in vitro propagation of Aloe vera sp. TIG Res. J. 1(2):116-119.

Murashige T, Skoog F (1962). A revised medium for rapid growth and bioassays with tobacco tissue cultures. Physiol Plant. 15: 473479.

Natali L, Sanchez IC, Cavallini A (1990). In vitro culture of Aloe barbadensis Mill: micropropagation from vegetative meristems. Plant Cell Tiss. Org. Cult. 20: 71-74.

Paoulomi Chatterjee, Bodhisattwa Chakraborty, Subhangkar Nandy (2013) Aloe vera plant Review with significant Pharmacological activities. Mintage j. Pharm. Med. Sci. 21-24.

Racchi ML (1987). Plant regeneration from callus cultures of Aloe ferox. Proc. Int. Congr. Plant tissue culture, Bogota. P. 33.

Radha Mahavi YR, Swapna RS, Pradeepkiran JA, Ismail SM, Madhuri E, Bhaskar M (2012). Protective role of ethanolic extract of Aloe vera anti-oxidant properties on liver and kidney of streptozotocin- induced diabetic rats. Digest J. Nano Materials Bio-structures 7:175 -184.
Rajasekaran S, Sivagnanam K, Ravi K, Subramanian S (2005). Antioxidant effect of Aloe vera gel extract in streptozotocininduced diabetes in rats. Pharmacol Rep. 57:90-96.

Reynolds T (2004). Aloes -The genus Aloe. Medicinal and Aromatic plants Industrial profiles USA 38.

Richwine AM, Tipton JL, Thompson GA (1995). Establishment of Aloe Gasteria and Hawothia shoot cultures from inflorescence explants. Hort Sci. 30(7):1443-1444.

Rines HW, Mc Coy TJ (1981). Tissue culture initiation and plant regeneration in hexapody species of oats. Crop Sci. 21:837-842.

Roy SC, Sarkar A (1991) In vitro regeneration and micropropagation of Aloe vera L. Sci Hort 47:107-113.

Rout GR, Reddy GM, Das P (2001). Study on in vitro clonal propagation of Paulownia tomentosa Steud evaluation of genetic fidelity through RAPD Marker. Silvae Genet. 50:208-212.

Sanchez IC, Natali L, Cavallini A (1988). In vitro culture of Aloe barbadensis Mill. Morphogenetic ability and nuclear DNA content. Plant Sci 55:53-59.

Sibi M (1982). Heritable epigenetic variation from in vitro tissue culture of Lycopersian esculentum (Var. Monalbo) In: E.D. Earle and Y. Demarly (Editors). Variability in plants regenerated from tissue culture. Proc NSFCNRS Congr.Osray.Prager, New York. pp. 228-244.

Silva-Pereira LC, Cardoso PC, Leite DS, Bahia MO, Bastos WR, Smith MA (2005). Cytotoxicity and Genotoxicity of low doses of mercury chloride and methyl mercury chloride on human lymphocytes in vitro. Brazilian J. Med. Biol. Res. 901-907.

ShekhRahman, Princeton Carter, Narayan Bhattarai (2017). Aloe vera for Tissue Engineering Applications. J. Funct Biomater. 8:6.

Tripathi BK, Bitallion C (1995) In vitro regeneration of Hedychium roxburgii blume through rhizome meristem culture. Hort Sci. 4:1117.

Velcheva M, Faltin Z, Vandi A, Eshdat Y, Perl A (2005).Regeneration of Aloe arborescens via organogenesis from young inflorescences. Plant Cell Tiss Org. Cult. 83:293- 301.

Walkey DGA, Nelly HA, Crisp P (1980). Rapid propagation of white cabbage by tissue culture. Sci Hort. 12: 2:99-107.

Werker E, Leshem B (1987). Structural changes during vitrification of carnation plantlets. Ann Bot. 59:377-385.

World Health Organization (WHO) (2005). Mercury in drinking water. http://www.who.int/water_sanitation_health/dwq/chemicals/mercur yfinal.pdf

Williams LD, Burdock GA, Shin E, Kim S Jo TH, Jones KN, Matulka RA (2010). Safety studies conducted on a proprietary high-purity Aloe vera inner leaf fillet preparation, Qmatrix. Regul. Toxicol. Pharmacol. 57:90-98.

Yagi A, Shoyama Y, Nishioka I (1983). Formation of tetra hydro anthracene glucosides by callus tissue of Aloe saponaria. Phytochemistry 22:1483-1484.

Yagi A, Sato Y, Shimomura K, Akasaki K, Tsuji H (2000). Distribution of verectin in Aloe vera leaves and verectin contents in clonally regenerated plants and the commercial gel powders by immunochemical screening. Planta Med. 66:180-182.

Yagi A, Sato Y, Miwa Y, Kabbash A, Moustafa S, Shimomura K and El-Bassuony A. (2006). Ribosomal DNA sequence analysis of different geographically distributed Aloe vera plants: comparison with clonally regenerated plants. Saudi Pharm. J. 14(3-4):208-211.

Zhou G, Ding H, Shi W, Cheng L (1999). Fast asexual propagation of Aloe vera. Horticul. 26(6):410-411. 